Мартынов А.В.

\title{
ОСНОВНЫЕ НАПРАВЛЕНИЯ РЕФОРМИРОВАНИЯ СОВРЕМЕННОЙ СИСТЕМЫ ГОСУДАРСТВЕННОГО КОНТРОЛЯ И НАДЗОРА В РОССИИ
}

\begin{abstract}
Аннотация. Предметом исследования в данной статья является современное состояние и перспективные направления реформирования системы государственного контроля и надзора. В последние годы проводятся значительные преобразования в законодательстве Российской Федерации о государственного контроле и надзоре, направленные на совершенствование деятельности контрольно-надзорных органов, в том числе внедрение системы риск-ориентированного государственного контроля и надзора. Предпринимаются попытки усовершенствовать систему органов исполнительной власти, осуществляющих функции по контролю и надзору с целью снижения избыточного воздействия на различные сферы рыночной экономики. При этом одним из главных вопросов, который обсуждается в последние время является принятие нового закона о государственном контроле и надзоре. Методологическую основу статьи составили современные научные методы, в том числе метод системного анализа, исторический метод, наблюдения, синтеза и анализа. Также активно используются социологические методы, статистический метод и метод экспертной оценки. Основными выводами проведенного исследования стало выявление основных проблем ресормирования современной системы государственного контроля и надзора. Автором определены три основных направления проведения реформ в этой области: во-первых, совершенствование действующего Федерального закона от 26 декабря 2008 г. №294-Ф3; во-вторых, оптимизация государственных структур и функций по осуществлению государственного контроля и надзора; в-третьих, разработка нового федерального закона о государственном контроле и надзоре. Проанализированы основные результаты проведенных преобразований.
\end{abstract}

Ключевые слова: административная реформа, государственный контроль, государственный надзор, административное право, исполнительная власть, государственные функции, сокращение избыточных функций, публичное управление, контрольно-надзорная деятельность, обеспечение законности.

Abstract. The research subject is the modern condition and the perspective directions of the state supervision system reforming. Recently, the significant reforms have been undertaken in the sphere of Russia's legislation about the state supervision, aimed at the improvement of oversight bodies' activities, including the introduction of a risk-oriented state supervision system. The attempts are made to improve the executive authorities system, responsible for the supervision and control, aimed at the decrease of the redundant influence on various spheres of the market economy. One of the main recently discussed questions is the adoption of a new law on the state supervision and control. The methodology of the research is composed of the modern scientific methods, including the systems analysis, the historical method, and the methods of observation, synthesis and analysis. The author also applies sociological methods, the statistical method and the method of expert assessment. In the result of the research the author formulates the main problems of the modern state supervision system reforming. The author defines three main directions of reforms in this sphere: firstly, the improvement of the current Federal Law of December 26, 2008 No. 294; secondly, the optimization of the state supervision structures and functions; thirdly, the development of the new federal law on the state control and supervision. The article analyzes the main results of the performed reforms.

Key words: decrease of redundant functions, state function, executive authority, administrative law, state supervision, state control, administrative reform, public administration, control and supervision activities, provision of legality.

$\mathrm{B}$ современном Российском государстве вот уже долгое время идет формирование системы государственного контроля и надзора. За более чем два десятилетия пройден трудный путь по построению и совершенствованию как системы государственного контроля и надзора, так и формированию законодательства, регламентирующего осуществление государственных функций по контролю и надзору. При этом стоит констатировать, что этот путь еще не закончен и предстоит еще полномасштабная реформа системы государственного контроля и надзора, которая соответствовала бы современному положению и развитию общественных, экономических и правовых отношений в Российском государстве.

Важность этой задачи трудно переоценить, так как практически любое современное государство руководствуется сформулированным еще в советское время принципом: «контролирует - значит руководит». Поэтому государственное управление 


\section{Административное и муниципальное право 1 (97) • 2016}

в Российском государстве основано на использовании таких административно-правовых форм и методов, которые непосредственным образом связаны с осуществлением контрольно-надзорной деятельности государственных органов и их должностных лиц.

Следует отметить, что системные проблемы в сфере государственного контроля и надзора связаны не только с отсутствием совершенной правовой основы для осуществления этих видов деятельности, но и определенным конформизмом и излишним консерватизмом в теории государственного контроля и надзора, которая основана на сложившихся правовых и организационных отношениях в советском государстве.

Так, во многом современные научные работы, посвященные различным аспектам государственного контроля и надзора, продолжают дублировать и ретранслировать сложившиеся идеи и взгляды, сформировавшиеся в советском административном праве, не учитывая изменившиеся в России государственное устройство, применяемые демократические принципы осуществления государственного управления, направленность и трансформацию действующего законодательства, новую практику, сложившуюся в деятельности органов, осуществляющих контрольные и надзорные функции.

На современном этапе совершенствование государственного контроля и надзора связано с чрезмерным влиянием государства на предпринимательскую (экономическую) деятельность субъектов свободного рынка.

В некоторых нормативных правовых актах напрямую говориться о необходимости исправления ситуации в этой области и скорейшем принятии мер, направленных на совершенствование законодательства о государственном контроле и надзоре.

Одним из таких правовых документов является Концепция долгосрочного социально-экономического развития Российской Федерации на период до 2020 года, утвержденная Распоряжением Правительства РФ от 17 ноября 2008 г. №1662-р[1]. В ней подчеркивается, что формирование институционной среды инновационного развития необходимо совершенствование системы контроля и надзора, предполагающее сокращение административных ограничений предпринимательской деятельности, обеспечение эффективной регламентации полномочий органов по контролю (надзору) и повышение гарантий защиты прав юридических лиц и индивидуальных предпринимателей при проведении государственного контроля (надзора).

Также необходимо сокращение количества контрольных и надзорных мероприятий, проводимых в отношении малого бизнеса, снижение издержек бизнеса, связанных с этими мероприятиями, ужесточение санкций в отношении сотрудников контрольных и надзорных органов, допускающих нарушения порядка проведения проверок, признание недействительными результатов проверок в случае грубых нарушений при их проведении, значительное сокращение внепроцессуальных проверок со стороны правоохранительных органов.

Важное значение имеет также Концепция снижения административных барьеров и повышения доступности государственных и муниципальных услуг на 2011-2015 годы, утвержденная Распоряжением Правительства РФ от 10 июня 2011 г. №1021p[2]. Целью настоящей Концепции являлось снижение административных барьеров, а среди задач обозначалось совершенствование разрешительной и контрольно-надзорной деятельности в различных сферах общественных отношений. В ней были отражены серьезные меры, направленные на снижение административных барьеров, что подразумевает совершенствование и оптимизацию системы государственного контроля и надзора.

Следует констатировать, что большинство из перечисленных указанных в Концепции мер не выполнено до настоящего времени, а сама Концепция по срокам действия утратила силу.

Вместе с тем, фактически все меры по совершенствованию государственного контроля и надзора, изложенные в данной Концепции, могут являться необходимой основой для разработки нового профильного федерального закона.

Важнейшей правовой основой для реформирования действующей системы государственного контроля и надзора является Указ Президента РФ от 7 мая 2012 г. №601 «0б основных направлениях совершенствования системы государственного управления»[3].

В нем поручено Правительству РФ, во-первых, до 1 января 2013 г. обеспечить замену в отдельных отраслях экономики избыточных и (или) неэффективных административных механизмов государственного контроля альтернативными рыночными механизмами, включая страхование ответственности; во-вторых, до 1 сентября 2012 г. обеспечить введение административного наказания в виде дисквалификации за грубое или неоднократное нарушение государственными и муниципальными служащими стандартов предоставления государственных и муниципальных услуг, а также за грубое нарушение ими порядка проведения проверочных и иных мероприятий при осуществлении контрольно-надзорных функций.

Следует отметить, что с 2012 года во всех без исключения Посланиях Президента РФ Федеральному Собранию РФ отводится значительное внимание проблемам реформирования и совершенствования государственного контроля и надзора[4]. 
Их всех посланий Президента РФ усматривается, что существует серьезная проблема в сфере государственного контроля и надзора, связанная с избыточным влиянием на бизнес, предпринимательские структуры, неэффективностью и многозатратностью деятельности контрольно-надзорных органов. При этом Президентом РФ, кроме сокращения избыточных функций и полномочий контрольно-надзорных органов, а также введения новых принципов государственного контроля и надзора, больше ничего не предлагается.

Таким образом, задачи, поставленные Президентом РФ, связанные с оптимизацией государственного контроля и надзора, разработкой и введением новых принципов его осуществления, не является простой и однозначной. Поэтому возникли ожидаемые сложности концептуального характера, а именно возник вопрос о совершенствовании действующего закона от 26 декабря 2008 г. №294-Ф3 или принятии нового федерального закона о государственном контроле и надзоре?

Ответ на данный вопрос имеет очень глубокий характер, так как напрямую зависит от тех положительных и негативных тенденций, сложившихся в сфере реформирования современной системы государственного контроля и надзора.

Для этого следует проанализировать текущую ситуацию и те предпосылки, которые напрямую влияют на пути совершенствования и реформирования действующей системы государственного контроля и надзора.

Bo-nервых, незавершенность административной реформы, в части построения единой, непротиворечивой и эффективной системы государственного контроля и надзора, основанную на новых принципах.

Так, Концепция административной реформы, утвержденная Распоряжением Правительства РФ от 25 октября 2005 г. №1789-р предусматривала реализацию мероприятий по 8 направлениям, в том числе было выделено направление «Оптимизация функций органов исполнительной власти и противодействие коррупции».

Основная идея заключалась в том, чтобы разграничить функции по контролю и надзору и унифицировать в этой части терминологию законодательных и других актов, что позволило бы надзор сосредоточить в государственных органах, а контроль рассматривать в качестве функций по проведению испытаний, измерений, экспертиз, осуществляемых субъектами рынка, аккредитованными в органах исполнительной власти в установленном порядке. Для этого после принятия соответствующих нормативных правовых актов предстояло выделить из действующих надзорных органов лаборатории, исследовательские и испы- тательские центры, сократить численность государственных служащих.

Во-вторых, по многим параметрам действующий Федеральный закон от 26 декабря 2008 г. №294-Ф3 «0 защите прав юридических лиц и индивидуальных предпринимателей при осуществлении государственного контроля (надзора) и муниципального контроля»[5] перестал выполнять основную функцию защиты прав и законных интересов юридических ли и индивидуальных предпринимателей от широкомасштабного воздействия контрольных и надзорных органов исполнительной власти. Это связано с тем, что многие положения данного закона не соответствовали требованиям и запросам предпринимательского сообщества, не позволяли в полной мере оградить от злоупотреблений со стороны должностных лиц контрольных и надзорных органов. Эффективность правовых механизмов, предусмотренных в законе, с каждым годом снижалась, а сам закон перестал быть основным регулятором контрольных и надзорных правоотношений, из-за большого числа исключений по отношения к значительном числу видов контрольной и надзорной деятельности.

Так, положения данного федерального закона не применяются к 9 видам контрольной и надзорной деятельности; положения закона, устанавливающие порядок организации и проведения проверок, не применяются при осуществлении 22 видов контрольной и надзорной деятельности; особенности организации и проведения проверок в части, касающейся вида, предмета, оснований проведения проверок, сроков и периодичности их проведения, уведомлений о проведении внеплановых выездных проверок и согласования проведения внеплановых выездных проверок с органами прокуратуры, могут устанавливаться другими федеральными законами при осуществлении еще 35 видов государственного контроля и надзора.

Таким образом, значительное число видов государственного контроля и надзора не подпадает полностью или в части под действие Федерального закона от 26 декабря 2008 г. №294-ФЗ. При этом количество таких видов государственного контроля и надзора с каждым годом все возрастает, то есть сфера действия данного федерального закона продолжает сужаться. Тем более это неправильно, когда значительная часть неурегулированных указанным федеральным законом контрольнонадзорных отношений имеет доминирующее значение, то есть охватывает наибольший круг поднадзорных объектов.

Все это поставило вопрос о совершенствовании действующего федерального закона от 26 декабря 2008 г. №294-Ф3, либо даже о принятии 


\section{Административное и муниципальное право 1 (97) 2016}

нового федерального закона о государственном контроле и надзоре.

$B$-третьих, следующей причиной является низкая эффективность контрольной и надзорной деятельности органов исполнительной власти и их должностных лиц.

Так, государство ежегодно несет огромные бюджетные расходы на проведение контрольных и надзорных мероприятий. По некоторым данным только на осуществление федерального государственного контроля и надзора до 100 млрд. в год. Это затраты, к которым относятся заработная плата работников контрольно-надзорных органов, командировочные расходы при осуществлении контрольно-надзорных мероприятий, материально-техническое обеспечение и др. Дополнительно около 2 млрд. рублей расходуется на финансирование участия экспертных организаций и экспертов в проведении проверок.

Несомненным также остается тот факт, что несмотря на большое количество проведенных проверок и огромные затраты на них, количество крупных аварий и происшествий продолжает оставаться высоким. Граждане не чувствуют себя в безопасности от различных видов угроз. Тем самым возникает вопрос об эффективности и целесообразности проводимых контрольных и надзорных мероприятий.

$B$-четвертых, важной причиной для реформирования системы государственного контроля и надзора является значительное число допущенных нарушений при проведении проверок органами исполнительной власти и их должностными лицами, осуществляющими функции по контролю и надзору.

Всего в 2014 году прокурорами выявлено и пресечено свыше 143 тыс. нарушений законодательства о защите прав предпринимателей, по результатам рассмотрения актов прокурорского реагирования к дисциплинарной и административной ответственности привлечено около 21 тыс. лиц, возбуждено 50 уголовных дел.

Прокурорами из предложенных более 900 тыс. проверок включены в плановые проверки лишь в отношении 400 тыс. хозяйствующих субъектов, при этом более $40 \%$ проверочных мероприятий проводились органами контроля и надзора совместно. В 2014 году прокурорами рассмотрено около 37 тыс. обращений о согласовании проведения выездных внеплановых проверок субъектов предпринимательства. При этом решения об отказе в их согласовании приняты в $40 \%$ случаев. Наибольшее количество отказов в согласовании внеплановых проверок прокурорами выносились в связи с отсутствием оснований для их проведения (61\%).

И наконец, в-пятых, назрела необходимость введения новой модели, основанной на иных прин- ципах осуществления государственного контроля и надзора.

Правительство РФ фактически склонилось к риск-ориентированной модели контрольной и надзорной деятельности. Эта модель предполагает, что «плотность» контроля и надзора должна зависеть от риска причинения вреда жизни, здоровью, окружающей среде, имуществу, безопасности в результате деятельности хозяйствующих субъектов.

Исходя из этого, можно выделить как минимум три основных направления по совершенствованию действующей системы государственного контроля и надзора:

- во-первых, совершенствование действующего Федерального закона от 26 декабря 2008 г. №294-Ф3;

- во-вторых, оптимизация государственных структур и функций по осуществлению государственного контроля и надзора;

- в-третьих, разработка нового федерального закона о государственном контроле и надзоре.

Рассмотрим более подробно каждое направление реформирования действующей системы государственного контроля и надзора.

1. На основании предложений, высказанных Президентом РФ в своем послании Федеральному Собранию в 2014 году, Правительству РФ были даны поручения, касающиеся внесения в законодательство РФ, изменений, предусматривающих:

во-первых, применение при планировании и осуществлении государственного контроля (надзора) и муниципального контроля системы оценки рисков потенциальной опасности видов экономической деятельности, осуществляемой хозяйствующими субъектами;

во-вторых, установление запрета на осуществление в соответствии с Федеральным законом от 26 декабря 2008 г. №294-Ф3 с 1 января 2016 г. в течение трех лет плановых контрольно-надзорных мероприятий в отношении субъектов малого предпринимательства, у которых по итогам предшествующих трех лет не выявлено существенных нарушений требований, установленных законодательством РФ, за исключением случаев выявления нарушений, создающих угрозу жизни и здоровья граждан.

Срок исполнения данных поручений Президента РФ был установлен до 15 июля 2015 года.

Федеральным законом от 13 июля 2015 г. №246-Ф3 «0 внесении изменений в Федеральный закон «0 защите прав юридических лиц и индивидуальных предпринимателей при осуществлении государственного контроля (надзора) и муниципального контроля»» [6] были внесены существенные изменения в Федеральный закон от 26 декабря 2008 г. №294-ФЗ. 
Во-первых, в профильный Федеральный закон была внесена новая статья 8.1 «Применение рискориентированного подхода при организации государственного контроля (надзора)». Этими изменениями в закон органам государственного контроля и надзора при организации отдельных видов государственного контроля и надзора, определяемых Правительством РФ, предписывается применять риск-ориентированный подход.

Кроме того, внесены и другие изменения в порядок осуществления контрольно-надзорных мероприятий.

Так, статья 9 Федерального закона от 26 декабря 2008 г. №294-Ф3 дополнена частью 1.2 следующего содержания: «Правительством РФ в отношении отдельных видов государственного контроля (надзора), определяемых в соответствии с частями 1 и 2 ст.8.1 настоящего Федерального закона, может быть установлено, что в случае, если деятельность юридического лица, индивидуального предпринимателя и (или) используемые ими производственные объекты отнесены к определенной категории риска, определенному классу (категории) опасности, плановая проверка таких юридического лища, индивидуального предпринимателя не проводится».

Также статья 9 дополнена частью 9.3 следующего содержания: «Правительством РФ может быть установлена иная периодччность проведения плановых проверок при осуществлении видов государственного контроля (надзора), определяемых в соответствии с частями 1 и 2 ст.8.1 настоящего Федерального закона, в зависимости от отнесения деятельности юридического лица, индивидуального предпринимателя и (или) используемых ими производственных объектов к определенной категории риска, определенному классу (категории) опасности».

При этом статья 12 дополнена частью 3.1 следующего содержания: «3.1 Правительством РФ в отношении отдельных видов государственного контроля (надзора), определяемых в соответствии с частями 1 и 2 ст.8.1 настоящего Федерального закона, может быть установлено, что в случае, если деятельность юридического лица, индивидуального предпринимателя и (или) используемые ими производственные объекты отнесены к определенной категории риска, определенному классу (категории) опасности, выездная плановая проверка таких юридического лица, индивидуального предпринимателя не проводится».

И наконец, статья 13 дополнена частью 1.1 следующего содержания: «1.1 Правительством РФ в отношении отдельных видов государственного контроля (надзора), определяемых в соответствии с частями 1 и 2 статьи 8.1 настоящего Федерально- го закона, может быть установлен сокращенный срок проведения проверки в случае, если деятельность юридического лица, индивидуального предпринимателя и (или) используемые ими производственные объекты отнесены к определенной категории риска, определенному классу (категории) опасности».

Положения федерального закона об рискориентированном подходе должны применяться с 1 января 2018 года, однако Правительство РФ вправе определить отдельные виды государственного контроля и надзора, которые с применением риск-ориентированного подхода могут осуществляться до 1 января 2018 года.

Во-вторых, внесены изменения, касающиеся «надзорных каникул» для субъектов малого предпринимательства.

Так, в Федеральный закон от 26 декабря 2008 г. №294-Ф3 была внесена специальная статья 26.1 «Особенности организации и проведения в 20162018 годах плановых проверок при осуществлении государственного контроля (надзора) и муниципального контроля в отношении субъектов малого предпринимательства».

Согласно ей, если иное не установлено частью 2 этой статьи, с 1 января 2016 года не проводятся плановые проверки в отношении юридических лиц, индивидуальных предпринимателей, отнесенных в соответствии с положениями ст.4 Федерального закона от 24 июля 2007 г. №209-ФЗ «О развитии малого и среднего предпринимательства в Российской Федерации» к субъектам малого предпринимательства, за исключением юридических лиц, индивидуальных предпринимателей, осуществляющих виды деятельности, перечень которых устанавливается Правительством РФ в соответствии с ч.9 ст. 9 Федерального закона от 26 декабря 2008 г. №294-Ф3.

2. Проблема сокращения и оптимизации контрольно-надзорных органов достаточно давно ставиться на разных уровнях власти, но видимых результатов в этой области пока не достигнуто.

Проблема оптимизации органов исполнительной власти, осуществляющих государственные функции по контролю и надзору, серьезным образом генерировалась в ходе административной реформы в 2006-2010 гг.

О необходимости объединения и сокращения контрольно-надзорных органов активно заговорили после закрытого доклада Генерального прокурора Ю.Я. Чайки на заседании Правительства РФ 15 октября 2009 года, посвященный проверке ведомств, обладающих контрольно-надзорными функциями. Как сообщается в информационных изданиях, «активность Генпрокуратуры затронула более 30 структур, как федеральных, так и ре- 


\section{Административное и муниципальное право 1 (97) • 2016}

гиональных: по словам слушателей доклада, в нем были названы подведомственные организации Минприроды, Минздрава, МВД, ФНС и ряд других. Глава Правительства Владимир Путин обвинил неизвестных чиновников в создании «прибыльного бизнеса» от подконтрольных организаций»[7]. В связи с этим, с 2009 по 2011 год в Администрации Президента РФ и Правительстве РФ последовательно обсуждались проекты слияния федерального Роспотребнадзора и подведомственного Минсельхозу Россельхознадзора, подведомственного Минздраву Росздравнадзора с тем же Роспотребнадзором. В октябре 2010 года Правительство РФ обсуждало вопрос дублирования контрольно-надзорных полномочий в Россельхознадзоре и Росрыболовстве. Ни один из этих проектов так и решением не стал[7].

Следующей попыткой реформирования контрольно-надзорных органов можно назвать предложения Президента РФ Д.А. Медведева о децентрализации контрольно-надзорных полномочий. Так, выступая на заседании Госсовета 26 декабря 2011 года Президент РФ Д.А. Медведев отмечал, что «значительное число властных полномочий, в первую очередь контрольно-надзорных, оказывающих существенное влияние на социально-экономические процессы в регионах, на инвестиционный климат, по-прежнему осуществляется территориальными органами федеральных органов исполнительной власти. ... Поэтому сегодня предлагается упор сделать прежде всего на делегировании регионам федеральных полномочий за счет передачи контрольно-надзорных и исполнительно-распорядительных полномочий в целом ряде сфер. Они перечислены, я не буду их перечислять, речь идет о санитарно-эпидемиологическом, ветеринарном надзоре, экологическом надзоре. Кто, как на территории, не руководители регионов, в самой большей степени заинтересованы в санитарно-эпидемиологическом либо экологическом благополучии территории; кто, как не руководитель территории, может организовать наиболее эффективное исполнение этих полномочий»[8].

Однако никаких изменений, по сделанным Президентом РФ предложениям, не произошло, а «инновационные» идеи децентрализации контрольнонадзорных полномочий остались в прошлом.

Новая попытка реформировать систему контрольно-надзорных органов происходит в настоящее время. Первые сообщения о планируемых сокращениях контрольно-надзорных органов появились в средствах массовой информации летом 2015 года.

По данным газеты «Коммерсантъ» «до 1 декабря правительство должно представить в Кремль предложения по оптимизации структуры и сокращению числа контрольных и надзорных ор- ганов. Предлагается подумать об исключении дублирующих функций и возможном объединении контрольно-надзорных органов «по сферам деятельности». Исполнение поручения президента расписано премьер-министром в Минюст, Минфин, Минтруд, Минэкономики (представить наработки нужно до 15 октября)»[7].

2 октября 2015 года Д.А. Медведев выступая на инвестиционном форуме отметил, что «нам нужно в первую очередь изменить качество государственного контроля. У нас огромное количество контрольно-надзорных органов. Их содержание нам не только не по карману, а они просто мешают. Они не по карману и бизнесу, который зачастую вынужден просто откупаться. Ежегодно у нас проводится более 2 млн. проверок, а государственный контроль должен быть именно умным, а не частым. Первые шаги по оптимизации мы уже сделали. Например, по объединению ряда органов, включая Федеральную антимонопольную службу и службу по тарифам»[9].

Действительно, в соответствии с Указом Президента РФ от 21 июля 2015 года №373 «0 некоторых вопросах государственного управления и контроля в сфере антимонопольного и тарифного регулирования»[10], была упразднена Федеральная служба по тарифам. Ее функции были переданы Федеральной антимонопольной службе.

По данным газеты «РБК», опубликованным в октябре 2015 года, «реформа контрольно-надзорных функций исполнительной власти может обернуться масштабной оптимизацией всей структуры правительства. Согласно рабочим материалам, ключевое предложение, которое влечет за собой и изменение всей структуры исполнительной власти, - это формирование системы федеральных надзоров. Речь идет о создании 9 надзоров (1.Федеральная служба по надзору в технологической, атомной, природоресурсной сферах и экологии; 2. Федеральная служба по техническому, экспортному надзору и финансовому мониторингу; 3. Федеральная служба по надзору в сфере антимонопольной, финансово-бюджетной и тарифной политики; 4. Федеральная служба по надзору в сфере транспорта; 5. Федеральная служба по надзору в отраслях социальной сферы; 6. Федеральная служба по надзору за оборотом наркотиков и регулированию алкогольного рынка; 7. Федеральная служба по надзору в сфере связи, информационных технологий и массовых коммуникаций; 8. Федеральная служба по надзору за исполнением судебных решений; 9. Федеральная служба по надзору в сфере защиты прав потребителей, ветеринарной и фитосанитарной деятельности). Эти ведомства предлагается подчинить напрямую Белому дому, сосредоточив в них все надзорные функции»[11]. 
Вместе с тем, 15 декабря 2015 года в средствах массовой информации появилось сообщение о том, что на правительственном уровне принято решение не предпринимать радикальных мер по изменению структуры контрольно-надзорных органов [12].

Как будет проходить данная реформа федеральных органов исполнительной власти, осуществляющих контрольные и надзорные функции, покажет время. Однако следует констатировать, что уже давно назрели кардинальные изменения в этой области, которые позволили бы сформировать более четкую, прозрачную и эффективную систему контрольно-надзорных органов исполнительной власти.

3. Наиболее сложным вопросом является проблема принятия нового федерального закона о государственном контроле и надзоре. Можно с уверенностью говорить о том, что Федеральный закон от 26 декабря 2008 г. №294-ФЗ морально и фактически устарел, в него внесено огромное количество изменений и дополнений, его положения уже не регулируют все виды государственного контроля и надзора.

Однако еще более серьезной проблемой является разработка и принятие нового закона о государственном контроле и надзоре, так как самые большие сложности возникают с принятием единой концепции контрольной и надзорной деятельности в Российской Федерации.

Начало работы над новым федеральным законом о государственном контроле и надзоре относится к середине 2013 года.

26 июня 2013 года Президентом РФ дается поручение №ПР-1391 Правительству РФ о разработке Концепции повышения результативности и оптимизации контрольно-надзорной деятельности на федеральном, региональном и муниципальном уровнях.

В начале 2014 года на сайте Открытого правительства РФ был опубликован проект Концепции повышения эффективности контрольно-надзорной деятельности органов государственной власти и органов местного самоуправления на 2014-2015 годы [13].

Этот документ включал следующие разделы: 1) Основные итоги реформирования системы государственного надзора и муниципального контроля в 2008-2013 гг.; 2) Общая характеристика системы государственного надзора и муниципального контроля в Российской Федерации; 3) Направления повышения эффективности контрольно-надзорной деятельности органов государственной власти и органов местного самоуправления; 4) Ожидаемые результаты реализации Концепции; 5) Финансовое обеспечение.

Необходимо отметить, что, на наш взгляд, по своему содержанию и глубине проработки вопро- сов, этот документ является одним из лучших за все время попыток реформирования системы государственного контроля и надзора.

И наконец, самое важное, что зафиксировано в проекте данной Концепции: «Формирование единой правовой основы деятельности контрольнонадзорных органов целесообразно осуществлять в два этапа.

В рамках первого этапа предполагается внести изменения в Федеральный закон от 26 декабря 2008 г. № 294-Ф3 «0 защите прав юридических лиц и индивидуальных предпринимателей при осуществлении государственного контроля (надзора) и муниципального контроля», предусматривающие введение системы оценки рисков потенциальной опасности и ее использования при планировании мероприятий по контролю, а также разработку соответствующих подзаконных актов. Выполнение первого этапа планируется провести в период с 2014-2016 годов.

Вторым этапом формирования единой правовой основы деятельности контрольно-надзорных органов представляется разработка и принятие федерального закона, кодифицирующего регулирование разрешительной деятельности органов государственной власти и органов местного самоуправления, разработка и принятие федерального закона, кодифицирующего регулирование в области государственного контроля (надзора), муниципального контроля, принятие мер, направленных на модернизацию законодательства об административных правонарушениях, а также реализация подпунктов 3 и 4 пункта 2 раздела III настоящей Концепции. Второй этап необходимо реализовать в период 2016-2018 годов» [14].

Интересным представляется и тот факт, что в настоящее время фактически реформирование системы государственного контроля и надзора происходит в рамках направлений и положений, зафиксированных в проекте не принятой Концепции.

Единственным формальным объяснением непринятия данной Концепции может служить Поручение Президента РФ Правительству РФ от 4 мая 2015 года №Пр-13 [15]. Это поручение Президента РФ было дано на основе предложений, высказанных в Послании Президента РФ Федеральному Собранию РФ 4 декабря 2014 года.

В пункте 1 данного поручения определяется, что в целях повышения эффективности контрольно-надзорной деятельности Правительству РФ необходимо внести в Государственную Думу ФС РФ проект федерального закона о федеральном, региональном и муниципальном контроле. Срок исполнения установлен до 1 сентября 2015 года.

В пункте 2 поручения Президента РФ предлагается рассмотреть вопрос о целесообразности 


\section{Административное и муниципальное право 1 (97) 2016}

включения в проект федерального закона о федеральном, региональном и муниципальном контроле в Российской Федерации положений, регламентирующих вопросы:

- разграничения сферы применения контрольной, надзорной и разрешительной деятельности, а также придания этим видам деятельности отдельного статуса с соответствующим правовым режимом;

- $\quad$ структуры (матрицы) функций и полномочий контрольных и надзорных органов на федеральном, региональном и муниципальном уровнях;

- перехода на риск-ориентированную модель реализации контрольных функций и полномочий;

- возможности осуществления государственного (муниципального) контроля в форме контрольной закупки.

Срок исполнения этого поручения установлен до 1 сентября 2015 года.

В соответствии с данным поручением Президента РФ Правительством РФ, а также другими федеральными органами исполнительной власти, научными и экспертными учреждениями, с начала 2015 года стала активно проводится работа по разработке нового федерального закона о государственном контроле, надзоре и муниципальном контроле.

Так, Приказом Минэкономразвития России от 26 января 2015 г. была создана Межведомственная рабочая группа по разработке проекта федерального закона о федеральном, региональном и муниципальном контроле.

Кроме Минэконоразвития РФ в работу над законопроектом о федеральном, региональном, муниципальном контроле и надзоре включилась также НИУ Высшая школа экономики, имеющая большой опыт в этой сфере [16].

Необходимо отметить, что в начале 2015 года Минэкономразвития РФ была разработана Концепция проекта федерального закона «0 государственном и муниципальном контроле и надзоре в Российской Федерации»[17]. В самом первом разделе данного документа указывается, что основной идеей законопроекта является создание правовой основы для формирования единой системы государственного и муниципального контроля (надзора) в Российской Федерации, обеспечивающей организацию и эффективное функционирование контрольно-надзорной деятельности органов государственной власти и органов местного самоуправления.

В Концепции также указывается, что целью будущего законопроекта является установление базовых, системообразующих правил организации и осуществления государственного и муниципаль- ного контроля и надзора в Российской Федерации, направленных на: а) построение прозрачной, доверительной и действенной системы взаимоотношений власти, граждан и бизнеса; б) снижение избыточного давления на бизнес; в) стимулирование добросовестной конкуренции; г) определение и установление четких границ разрешительной деятельности, государственного и муниципального контроля и надзора; д) существенное повышение эффективности и результативности контрольнонадзорной деятельности; е) эффективное использование бюджетных средств.

Разработчиками Концепции отмечается, что принятие законопроекта будет способствовать в целом совершенствованию государственного и муниципального управления, модернизации отечественной экономики, развитию добросовестной конкуренции, предотвращению коррупции и других злоупотреблений в органах государственной власти и местного самоуправления.

При этом предметом правового регулирования нового законопроекта будут являться отношения, связанные с установлением правовых и организационных основ системы государственного и муниципального контроля и надзора в Российской Федерации, предусматривающих определение целей, задач и принципов осуществления различных видов государственного и муниципального контроля и надзора, их ресурсного обеспечения и оценки эффективности и результативности, в том числе такие вопросы, как:

- разграничение государственного и муниципального контроля, государственного и муниципального надзора и разрешительной деятельности;

- выбор форм государственного регулирования, определение требований законодательства и установление принципов применения мер ответственности;

- ведение перечня видов государственного и муниципального контроля и надзора;

- ведение алгоритмов и руководств по осуществлению контрольно-надзорных мероприятий на основе рискового подхода;

- $\quad$ ведение базы данных по учету и анализу результатов контрольно-надзорных мероприятий;

- оценка обоснованности присвоения категорий угрозы и вероятности ее наступления, а также иных ключевых параметров реализации рискового подхода при осуществлении государственного и муниципального контроля и надзора;

- моделирование и прогнозирование контрольно-надзорной деятельности;

- формирование контрольно-надзорными органами планов контрольно-надзорных мероприятий; 
- исполнение и мониторинг контрольно-надзорных мероприятий;

- оформление результатов контрольно-надзорных мероприятий;

- учет и анализ результатов контрольно-надзорной деятельности в интересах планирования контрольно-надзорных мероприятий;

- обеспечение прозрачности и подотчетности деятельности контрольно-надзорных органов;

- оценка эффективности и результативности контрольно-надзорной деятельности [18].

Итогом работы Минэкономразвития и НИУ Высшая школа экономики стала разработка весной 2015 года двух параллельных законопроектов о федеральном, региональном, муниципальном контроле и надзоре.

Так, в 21 апреля 2015 года Минэкономразвития РФ подготовило первый законопроект о федеральном, региональном и муниципальном контроле и надзоре, который был отправлен в Администрацию Президента РФ и другие заинтересованные государственные структуры для ознакомления, принятия замечаний и получения согласований на законопроект.

Данный законопроект включал 131 статью, разделенные на 12 глав. Среди принципиально новых положений законопроекта отличающего его от Федерального закона от 26 декабря 2008 г. №294-Ф3 можно назвать ниже следующие:

Во-первых, новый федеральный закон предполагается распространить не только на юридических лиц и индивидуальных предпринимателей, но и на граждан, в отношении которых осуществляется государственный контроль и надзор, муниципальный контроль и надзор (ст.1).

Во-вторых, в проекте федерального закона разграничены термины контроль и надзор. Под государственным и муниципальным надзором предлагается понимать деятельность соответственно уполномоченных органов государственной власти Российской Федерации, органов государственной власти субъектов Российской Федерации, органов местного самоуправления, иных уполномоченных органов и организаций, направленная на предупреждение, выявление и пресечение нарушений обязательных требований, и осуществляемая в целях обеспечения законности и безопасности в соответствующих сферах деятельности, по результатам которой могут применяться меры административного принуждения. Меры административного принуждения, применяемые к физическим и юридическим лицам по результатам государственного и муниципального надзора, устанавливаются законодательством об административных правонарушениях (ст.6).

Под государственным и муниципальным контролем предлагается понимать деятельность со- ответственно уполномоченных органов государственной власти Российской Федерации, органов государственной власти субъектов Российской Федерации и органов местного самоуправления, иных уполномоченных органов и организаций, направленная на предупреждение, выявление и пресечение нарушений обязательных требований в целях обеспечения законности, безопасности и иных целей особого порядка правового регулирования в соответствующих сферах деятельности, по результатам которой могут применяться меры административного принуждения и иные правоограничительные меры.

В-третьих, в статье 8 проекта федерального закона перечислены все виды федерального государственного контроля и надзора; в статье 9 все виды регионального государственного контроля и надзора; в статье 10 все виды муниципального контроля и надзора, установив тем самым исчерпывающий перечень видов контрольной и надзорной деятельности.

В-четвертых, в новом законе впервые определены субъекты, государственного и муниципального контроля и надзора (ст.11), предмет государственного и муниципального контроля и надзора (ст.12), объекты государственного и муниципального контроля и надзора (ст.13), а также зафиксировано понятие «разрешительная деятельность органов государственной власти и органов местного самоуправления» (ст.14).

B-пятых, в проекте закона перечислены новые принципы организации и осуществления государственного контроля и надзора, а также раскрыто их содержание, что никогда не было в нашем законодательстве.

В-шестых, новеллой является глава 3, посвященная организации государственного и муниципального контроля и надзора. В ней закреплены общие вопросы организации государственного и муниципального контроля и надзора (ст.26); виды планирования государственного и муниципального контроля и надзора (ст.27); положения, касающиеся роли административных регламентов осуществления государственного и муниципального контроля и надзора (ст.30); а также вопросы государственного учета граждан, юридических лиц, индивидуальных предпринимателей и объектов для целей государственного и муниципального контроля и надзора (ст.31).

В-седьмых, глава 4 проекта федерального закона, устанавливает систему управления рисками причинения вреда при осуществлении государственного и муниципального контроля и надзора.

В-восьмых, в главе 5 впервые на законодательном уровне предлагается закрепить формы, методы и мероприятия государственного и муниципально- 


\section{Административное и муниципальное право 1 (97) 2016}

го контроля и надзора. Так, разработчиками нового федерального закона предлагается закрепить следующие формы осуществления государственного контроля и надзора, и муниципального контроля и надзора: 1) проверка; 2) режим постоянного контроля (надзора); 3) осмотр; 4) рейдовый осмотр; 5) досмотр; 6) досмотр граждан, личный досмотр; 7) сбор информации; 8) опрос; 9) получение пояснений (объяснений); 10) наблюдение; 11) мониторинг; 12) контрольная закупка (ст.52). В законопроекте раскрывается содержание каждой формы контрольной и надзорной деятельности.

В-девятых, к новеллам нового законопроекта следует отнести и главу 7, посвященную независимой оценке соблюдения юридическими лицами и индивидуальными предпринимателями обязательных требований. В частности, предусмотрена возможность использования негосударственных форм контроля для целей государственного и муниципального контроля и надзора. К таким формам отнесены: декларирование юридическими лицами и индивидуальными предпринимателями ответственности (ст.91), инспекционный контроль (ст.92), контроль саморегулируемой организации за деятельностью своих членов (ст.93).

В-десятых, в проекте федерального закона включена глава 8, посвященная профилактике нарушений обязательных требований.

И наконец, в-одиннадцатых, проект федерального закона содержит главу 10, предусматривающие положения об эффективности и результативности государственного и муниципального контроля и надзора.

В марте 2015 года также был разработан и представлен НИУ Высшая школа экономики проект федерального закона «0 государственном контроле и муниципальном контроле в Российской Федерации». Данный законопроект включает 69 статей, разделенных на 11 глав. Среди положений законопроекта, обращающих на себя внимание, можно указать следующие:

Во-первых, законопроект продолжает линию Федерального закона от 26 декабря 2008 г. №294Ф3, об изъятии из сферы применения большого числа видов государственного контроля и надзора. Так, положения данного проекта федерального закона не применяются или ограниченно применяются более чем к 60 видам государственного контроля и надзора.

Во-вторых, важное значение имеет разграничение в законе понятий государственного контроля и надзора. Под государственным (муниципальным) контролем предлагается понимать деятельность органов государственного (муниципального) контроля по проведению оценки соответствия обязательным требованиям деятель- ности хозяйствующих субъектов, принадлежащих им объектов, производимой и (или) реализуемой продукции, а также по пресечению и устранению последствий выявленных нарушений обязательных требований в целях защиты основ конституционного строя, нравственности, здоровья, прав и законных интересов других лиц, обеспечения обороны страны и безопасности государства. Под государственным (муниципальным) надзором предлагается понимать деятельность органов государственного (муниципального) контроля, осуществляемая посредством проведения оценки соответствия обязательным требованиям хозяйствующего субъекта, принадлежащих ему объектов, производимой и (или) реализуемой продукции в ходе осуществления деятельности, производства и (или) реализации продукции.

Вряд ли можно назвать удачными и отражающими реальную деятельность по осуществлению государственного контроля и государственного надзора, предложенные в законопроекте определения, однако сама линия на их разграничение является верной.

В-третьих, в главе 2 проекта федерального закона, посвященной организации государственного (муниципального) контроля, закреплены формы и методы государственного (муниципального) контроля. Формами государственного (муниципального) контроля являются: 1) предварительный государственный (муниципальный) контроль, 2) государственный (муниципальный) надзор.

При этом в законопроекте закреплены методы государственного (муниципального) контроля, к числу которых отнесены: 1) истребование документов (информации) у хозяйствующих субъектов, запрос документов (информации) у государственных органов и органов местного самоуправления, подведомственных им организаций; 2) устный опрос и получение письменных пояснений (объяснений) должностных лиц и работников хозяйствующих субъектов; 3) обследование, включая: а) осмотр территорий, зданий, сооружений, помещений и иных объектов; б) досмотр продукции, транспортных средств и перевозимых грузов; в) описание технологических процессов, оборудования, инвентаря, средств коллективной и индивидуальной защиты; г) отбор проб (образцов) продукции, объектов окружающей и производственной среды для проведения экспертизы; д) проведение измерений с использованием инструментальных средств; е) фотосъемку, аудио- и видеозапись обследуемых объектов; 4) экспертиза, включая исследования и испытания проб (образцов) продукции, объектов окружающей и производственной среды; 5) получение информации (наблюдение) с использованием технических 
средств удаленного контроля и в информационнотелекоммуникационной сети «Интернет».

В статье 14 предпринята попытка перечислить все существующие виды федерального, регионального и муниципального контроля и надзора в Российской Федерации.

В целом, оценивая данный законопроект, можно утверждать, что он требует значительной доработки.

19 мая 2015 года первый вариант законопроекта, подготовленный Минэкономразвития, был рассмотрен Подкомиссией по совершенствованию контрольных и разрешительных функций федеральных органов исполнительной власти[19] при Правительственной по проведению административной реформы. Как отмечается на сайте Открытого правительства РФ: «Экспертный совет при Правительстве РФ подготовил свои замечания и предложения по законопроекту. В частности, в проекте документа, по мнению экспертов, недостаточно прописан понятийный аппарат, а разделение понятий «контроль» и «надзор» выглядит пока не очень удачным. Кроме того, по мнению экспертов, в законопроекте недостаточно четко определена сфера его применения и не полностью прописан предмет контрольно-надзорной деятельности. Вопросы у экспертов есть также к разграничению форм и методов контроля, а также способам оценки эффективности контрольно-надзорных органов»[20].

27 июля 2015 года законопроект о государственном контроле, доработанный Минэкономразвития с учетом замечаний экспертного и предпринимательского сообществ вновь был внесен на рассмотрение подкомиссии по совершенствованию контрольных (надзорных) и разрешительных функций федеральных органов исполнительной власти при Правительственной комиссии по проведению административной реформы.

По мнению экспертов, доработанный вариант законопроекта Минэкономразвития также имеет множество замечаний.

Основную критику к законопроекту высказало Контрольное управление Президента РФ также считают, что в законопроекте не хватает чёткого целеполагания. «Фактически Минэкономразвития создало большой конструктор «Лего». Контрольно-надзорные органы могут найти там свой элемент и использовать его. Что из этого «Лего» можно сделать в итоге - неясно. Тот ключевой вопрос, который ставился - что мы в конце концов получим, - остался нерешенным», - отметил заместитель начальника Контрольного управления Президента РФ Валентин Летуновский.

В доработке законопроект нуждается и в части управления рисками, считают участники обсуждения. Член Экспертного совета при Правительстве
РФ Александр Брагин, в частности, обратил внимание на нечеткость понятийного аппарата в описании риск-ориентированной модели контроля и надзора. Так, в законопроекте фигурируют такие понятия, как «классы опасности», «критерии риска», «индикаторы риска», «профили риска», из которых тяжело сложить целостную картину. Есть у экспертов замечания и по классификации категорий рисков.

Некоторые нормы закона, по словам Александра Брагина, вызывают серьезные опасения у предпринимательского сообщества. Речь идет, в частности, о формах мероприятий контроля, многие из которых задействованы исходя из оперативно-розыскной деятельности, что в совокупности создает у представителей бизнеса ощущение о репрессивном характере закона, признал член Экспертного совета.

Представители контрольно-надзорных ведомств сошлись во мнении, что доработанный законопроект станет большим шагом в повышении качества контрольно-надзорной деятельности и, несмотря на ряд неурегулированных разногласий, должен быть взят за основу.

По итогам обсуждения министр РФ Михаил Абызов поручил Экспертному совету при Правительстве РФ составить единый реестр замечаний и предложений к законопроекту и представить его в Минэкономразвития для рассмотрения на заседании межведомственной рабочей группы по этому вопросу, которое, как ожидается, состоится 30 июля[21].

31 июля 2015 года также на сайте Открытого правительства появляется новость о том, что «по мнению участников обсуждения - экспертов, представителей госорганов и бизнес-сообщества - третья версия разрабатываемого Минэкономразвития законопроекта стала на уровень лучше предыдущей. В ней учтены многие звучавшие ранее замечания: решено отказаться от разграничения понятий контроля и надзора, сохранить уведомление о плановых проверках, предусмотрев механизм борьбы со злоупотреблениями. Доработаны положения, связанные с управлением рисками и раздел, касающийся форм и мероприятий государственного и муниципального контроля - из него, в частности, исключен личный досмотр.

В то же время целый ряд замечаний к законопроекту так и не нашли отражения в доработанной версии документа. Между тем, его планируется внести в Правительство уже 5 августа, а в Госдуму он, согласно поручению Президента РФ, должен поступить к 1 сентября. По итогам состоявшегося обсуждения Минэкономразвития поручено ещё раз доработать документ: уточнить в нём целеполагание закона (устранение избыточного государ- 
ственного и муниципального контроля и повышение его эффективности), сферы его применения, определить принципы использования негосударственных форм контроля (в том числе деятельности саморегулируемых организаций)»[22].

Именно на этой стадии в очередной раз были нивелированы базовые концептуальные положения о государственном контроле и надзоре, в том числе предусматривающие разграничение этих видов деятельности; которое также содержалось в поручении Президента РФ от 4 января 2015 г. №Пр-13 (пункт 2).

В августе 2015 года Министр М.Абызов обращается со служебной запиской на имя возглавляющего Правительственную комиссию по проведению административной реформы вице-премьера С. Приходько с просьбой перенести срок внесения законопроекта в Госдуму на 15 октября, поскольку, по мнению большинства экспертов, доработать законопроект до приемлемого качественного уровня в определенные президентским поручением сроки было невозможно.

Однако уже 7 сентября 2015 г. на сайте Открытого правительства РФ появляется сообщение о том, что Экспертный совет настаивает на доработке законопроекта о госконтроле. Согласно заключения Экспертного совета при Правительстве РФ, текущая версия законопроекта о государственном и муниципальном контроле и надзоре, которую разработало Минэкономразвития, создает риск увеличения административного давления на бизнес. Эксперты также считают, что обсуждение законопроекта и его доработка должны быть продолжены.

Более того, как подчеркивается в информационном сообщении: «Законопроект уже неоднократно дорабатывался Минэкономразвития, однако и в четвертой его версии министерство не смогло учесть многие замечания и представителей экспертного и предпринимательского сообщества. Более того, документ так и не был внесен министерством в Правительство в установленном порядке: не была проведена оценка регулирующего воздействия, не было проведено согласование с заинтересованными ведомствами»[23].

И наконец, 20 октября 2015 года на сайте 0ткрытого правительства появляется сообщение о переносе сроков принятия федерального закона о государственном контроле на 2016 год. В нем также говорится о принципиальных претензиях и замечаниях к законопроекту, разработанному Минэкономразвития.

Поразительно, но факт, но в этом же новостном сообщении содержится информация о том, что Экспертный совет не считает возможным поддержать проект закона в представленной редакции и рекомендует продолжить ее доработку с учетом имеющихся замечаний в течение 2016 года. В текущей экономической ситуации, по мнению значительной части предпринимательского сообщества, бизнесу нельзя предлагать неясные правила, которые приводят к рискам усиления административной нагрузки[24].

Таким образом, несмотря на поручение Президента РФ, его ежегодные послания Федеральному Собранию об ускорении работы по разработке нового закона о государственном контроле и надзоре, работа ведется с большим опозданием, и в отсутствие четкой выработанной концепции понимания и содержания контрольной и надзорной деятельности. Остается надеяться, что работа над законопроектом продолжится, а не будет прекращена и со временем забыта, как это происходило со многими другими инициативами Президента РФ и Правительства РФ.

\section{Библиография:}

1. СЗ РФ. 2008. №47. Ст.5489.

2. СЗ РФ. 2011. №26. Ст.3826.

3. СЗ РФ. 2012. №19. Ст.2338.

4. Послание Президента РФ Федеральному собранию РФ 12 декабря 2012 г. // Российская газета. 2012.13 декабря. №287; Послание Президента РФ Федеральному собранию РФ 12 декабря 2013 г. // Российская газета. 2013. 13 декабря. №282; Послание Президента РФ Федеральному Собранию РФ 4 декабря 2014 г. // Российская газета. 2014. 5 декабря. №278; Послание Президента РФ Федеральному Собранию РФ 3 декабря 2015 г. // СПС «КонсультантПлюс».

5. СЗ РФ. 2008. №52 (ч.1). Ст.6249.

6. СЗ РФ. 2015 . №29 (ч.1). Ст.4372.

7. Контрольные ведомства лишают чаевых // http://www.kommersant.ru/doc/2799952.

8. http://kremlin.ru/events/president/news/14139.

9. http://government.ru/news/19887/\#dam2010.

10. СЗ РФ. 2015. №30. Ст.4571.

11. Путину предложат сократить правительства // РБК // http://www.rbc.ru/economics/15/10/2015/561fdf359a794 761d7a9ec5d.

12. Белоуслов: структуру контрольно-надзорных органов радикально не изменят // РИА Новости // http://ria.ru/ society/20151215/1342376565.html.

13. Проект Концепции до настоящего времени так и не был утвержден. 
14. Проект Концепции повышения эффективности контрольно-надзорной деятельности органов государственной власти и органов местного самоуправления на 2014-2015 годы // Документ не принят и официально опубликован не был.

15. Документ опубликован не был.

16. Специалистами НИУ Высшей школы экономики на протяжении нескольких лет совместно с Минэкономразвития РФ подготавливаются и публикуются аналитические доклады о состоянии контрольно-надзорной деятельности в России. См.: Состояние системы государственного контроля в Российской Федерации / Коллектив авторов; Гос. ун-т - Высшая школа экономики. - М.: Изд. дом Гос. ун-та - Высшей школы экономики, 2010. - 304 с.; Состояние системы государственного контроля в Российской Федерации: Аналитический доклад. - 2011. - М.: МАКС Пресс, 2011. - 400 с.; Контрольно-надзорная деятельность в Российской Федерации: Аналитический доклад. - 2013. - М.: МАКС Пресс, 2014. - 2-е изд., доп. - 320 с.; Контрольно-надзорная деятельность в Российской Федерации: Аналитический доклад. - 2014. - М.: МАКС Пресс, 2015. - 120 с.

17. Концепция проекта федерального закона «О государственном и муниципальном контроле и надзоре в Российской Федерации» была утверждена Протоколом заседания Межведомственной рабочей группы по разработке проекта федерального закона о федеральном, региональном и муниципальном контроле в Российской Федерации Минэкономразвития РФ от 6 марта 2015 г. №16-ОФ (пункт 2.2) // Документ опубликован не был.

18. Концепция проекта федерального закона «0 государственном и муниципальном контроле и надзоре в Российской Федерации», разработана Минэкономразвития РФ // Документ опубликован не был.

19. Состав подкомиссии по совершенствованию контрольных (надзорных) и разрешительных функций федеральных органов исполнительной власти, утвержден протоколом заседания Правительственной комиссии по проведению административной реформы от 14 апреля 2015 г. №1 (141) (раздел IV) // Документ опубликован не был.

20. Законопроект о госконтроле рассмотрела Правительственная подкомиссия. 19 мая 2015 г. Лента новостей // http://контроль-надзор.pф/news/view/55d35d288e3e213d22f3576e.

21. Госконтроль: права и обязанности ведомств и бизнеса определит закон. 27 июля 2015 г. Лента новостей // http://контроль-надзор.pф/news/view/55d36a948e3e213d22f35775.

22. Контроль и надзор: поручения подкомиссии. 31 июля 2015 г. Лента новостей // http://контроль-надзор.рф/ news/view/55d36baf8e3e213d22f35776.

23. Открытое правительство настаивает на доработке законопроекта о госконтроле. 7 сентября 2015 г. Лента новостей // http://контроль-надзор.pф/news/view/55f00e838a8925d17f55bffa.

24. Эксперты рекомендуют продолжить доработку законопроекта о госконтроле в течение 2016 года. 20 октября 2015 года. Лента новостей // http://контроль-надзор.pф/news/view/564472558a8925d17f55c00a.

25. Соломатина Е.А. К вопросу о преподавании курса учебной дисциплины «Административное право зарубежных стран» в юридических вузах // NB: Административное право и практика администрирования. - 2014. - 1. - С. 46 - 52. DOI: 10.7256/2306-9945.2014.1.11165. URL: http://www.e-notabene.ru/al/article_11165.html

26. Тихонова А.В. Надзор за иностранными врачами в Российской империи в первой половине XIX века // Исторический журнал: научные исследования. - 2014. - 4. - С. 456 - 463. DOI: 10.7256/2222-1972.2014.4.13937.

27. Лапина М.А. О необходимости систематизации мер государственного принуждения в законодательстве российской федерации // Финансовое право и управление. - 2015. - 2. - C. 114 - 119. DOI: 10.7256/2310-0508.2015.2.15647.

28. Котляров Ю.В. Правоприменительные аспекты применения мер государственного принуждения в сфере технического регулирования // Финансовое право и управление. - 2015. - 2. - С. 273 - 278. DOI: 10.7256/23100508.2015.2.15871.

29. Жирина М.В. Реформа российского образования: выбор адекватной модели // Политика и Общество. - 2014. - 10. - C. 1161 - 1167. DOI: 10.7256/1812-8696.2014.10.10900.

30. Можуга В.В. Юридическая природа решений Конституционного суда Российской Федерации в их соотношении с решениями суда ЕврАзЭС // Право и политика. - 2014. - 1. - С. 37 - 41. DOI: 10.7256/1811-9018.2014.1.10647.

\section{References (transliterated):}

1. SZ RF. 2008. №47. St.5489.

2. SZ RF. 2011. №26. St.3826.

3. SZ RF. 2012. №19. St.2338.

4. Poslanie Prezidenta RF Federal'nomu sobraniyu RF 12 dekabrya 2012 g. // Rossiiskaya gazeta. 2012. 13 dekabrya. №287; Poslanie Prezidenta RF Federal'nomu sobraniyu RF 12 dekabrya 2013 g. // Rossiiskaya gazeta. 2013. 13 dekabrya. №282; Poslanie Prezidenta RF Federal'nomu Sobraniyu RF 4 dekabrya 2014 g. // Rossiiskaya gazeta. 2014. 5 dekabrya. №278; Poslanie Prezidenta RF Federal'nomu Sobraniyu RF 3 dekabrya 2015 g. // SPS «Konsul'tantPlyus».

5. $\quad$ SZ RF. 2008. №52 (ch.1). St.6249.

6. SZ RF. 2015. №29 (ch.1). St.4372.

7. Kontrol'nye vedomstva lishayut chaevykh // http://www.kommersant.ru/doc/2799952.

8. http://kremlin.ru/events/president/news/14139.

9. http://government.ru/news/19887/\#dam2010.

10. SZ RF. 2015. №30. St.4571.

11. Putinu predlozhat sokratit' pravitel'stva // RBK // http://www.rbc.ru/economics/15/10/2015/561fdf359a794761d7a9ec5d.

12. Belouslov: strukturu kontrol'no-nadzornykh organov radikal'no ne izmenyat // RIA Novosti // http://ria.ru/ society/20151215/1342376565.html. 


\section{Административное и муниципальное право 1 (97) • 2016}

13. Proekt Kontseptsii do nastoyashchego vremeni tak i ne byl utverzhden.

14. Proekt Kontseptsii povysheniya effektivnosti kontrol'no-nadzornoi deyatel'nosti organov gosudarstvennoi vlasti i organov mestnogo samoupravleniya na 2014-2015 gody // Dokument ne prinyat i ofitsial'no opublikovan ne byl.

15. Dokument opublikovan ne byl.

16. Spetsialistami NIU Vysshei shkoly ekonomiki na protyazhenii neskol'kikh let sovmestno s Minekonomrazvitiya RF podgotavlivayutsya i publikuyutsya analiticheskie doklady o sostoyanii kontrol'no-nadzornoi deyatel'nosti v Rossii. Sm.: Sostoyanie sistemy gosudarstvennogo kontrolya v Rossiiskoi Federatsii / Kollektiv avtorov; Gos. un-t - Vysshaya shkola ekonomiki. - M.: Izd. dom Gos. un-ta - Vysshei shkoly ekonomiki, 2010. - 304 s.; Sostoyanie sistemy gosudarstvennogo kontrolya v Rossiiskoi Federatsii: Analiticheskii doklad. - 2011. - M.: MAKS Press, 2011. - 400 s.; Kontrol'no-nadzornaya deyatel'nost' v Rossiiskoi Federatsii: Analiticheskii doklad. - 2013. - M.: MAKS Press, 2014. - 2-e izd., dop. - 320 s.; Kontrol'nonadzornaya deyatel'nost' v Rossiiskoi Federatsii: Analiticheskii doklad. - 2014. - M.: MAKS Press, 2015. - 120 s.

17. Kontseptsiya proekta federal'nogo zakona «O gosudarstvennom i munitsipal'nom kontrole i nadzore v Rossiiskoi Federatsii» byla utverzhdena Protokolom zasedaniya Mezhvedomstvennoi rabochei gruppy po razrabotke proekta federal'nogo zakona o federal'nom, regional'nom i munitsipal'nom kontrole v Rossiiskoi Federatsii Minekonomrazvitiya RF ot 6 marta 2015 g. №16-OF (punkt 2.2) // Dokument opublikovan ne byl.

18. Kontseptsiya proekta federal'nogo zakona «0 gosudarstvennom i munitsipal'nom kontrole i nadzore v Rossiiskoi Federatsii», razrabotana Minekonomrazvitiya RF // Dokument opublikovan ne byl.

19. Sostav podkomissii po sovershenstvovaniyu kontrol'nykh (nadzornykh) i razreshitel'nykh funktsii federal'nykh organov ispolnitel'noi vlasti, utverzhden protokolom zasedaniya Pravitel'stvennoi komissii po provedeniyu administrativnoi reformy ot 14 aprelya 2015 g. №1 (141) (razdel IV) // Dokument opublikovan ne byl.

20. Zakonoproekt o goskontrole rassmotrela Pravitel'stvennaya podkomissiya. 19 maya 2015 g. Lenta novostei //http:// kontrol'-nadzor.rf/news/view/55d35d288e3e213d22f3576e.

21. Goskontrol': prava i obyazannosti vedomstv i biznesa opredelit zakon. 27 iyulya 2015 g. Lenta novostei // http://kontrol'nadzor.rf/news/view/55d36a948e3e213d22f35775.

22. Kontrol' i nadzor: porucheniya podkomissii. 31 iyulya 2015 g. Lenta novostei // http://kontrol'-nadzor.rf/news/ view/55d36baf8e3e213d22f35776.

23. Otkrytoe pravitel'stvo nastaivaet na dorabotke zakonoproekta o goskontrole. 7 sentyabrya 2015 g. Lenta novostei // http://kontrol'-nadzor.rf/news/view/55f00e838a8925d17f55bffa.

24. Eksperty rekomenduyut prodolzhit' dorabotku zakonoproekta o goskontrole v techenie 2016 goda. 20 oktyabrya 2015 goda. Lenta novostei // http://kontrol'-nadzor.rf/news/view/564472558a8925d17f55c00a.

25. Solomatina E.A. K voprosu o prepodavanii kursa uchebnoi distsipliny «Administrativnoe pravo zarubezhnykh stran» v yuridicheskikh vuzakh // NB: Administrativnoe pravo i praktika administrirovaniya. - 2014. - 1. - C. 46 - 52 . DOI: 10.7256/2306-9945.2014.1.11165. URL: http://www.e-notabene.ru/al/article_11165.html

26. Tikhonova A.V. Nadzor za inostrannymi vrachami v Rossiiskoi imperii v pervoi polovine XIX veka // Istoricheskii zhurnal: nauchnye issledovaniya. - 2014. - 4. - C. 456 - 463. DOI: 10.7256/2222-1972.2014.4.13937.

27. Lapina M.A. O neobkhodimosti sistematizatsii mer gosudarstvennogo prinuzhdeniya $\mathrm{v}$ zakonodatel'stve rossiiskoi federatsii // Finansovoe pravo i upravlenie. - 2015. - 2. - C. 114 - 119. DOI: 10.7256/2310-0508.2015.2.15647.

28. Kotlyarov Yu.V. Pravoprimenitel'nye aspekty primeneniya mer gosudarstvennogo prinuzhdeniya v sfere tekhnicheskogo regulirovaniya // Finansovoe pravo i upravlenie. - 2015. - 2. - C. 273 - 278. DOI: 10.7256/2310-0508.2015.2.15871.

29. Zhirina M.V. Reforma rossiiskogo obrazovaniya: vybor adekvatnoi modeli // Politika i Obshchestvo. - 2014. - 10. - C. 1161 - 1167. DOI: 10.7256/1812-8696.2014.10.10900.

30. Mozhuga V.V. Yuridicheskaya priroda reshenii Konstitutsionnogo suda Rossiiskoi Federatsii v ikh sootnoshenii s resheniyami suda EvrAzES // Pravo i politika. - 2014. - 1. - C. 37 - 41. DOI: 10.7256/1811-9018.2014.1.10647. 